\title{
Preferred service quality in domestic airlines: South Africa versus Italy
}

\author{
J. W. de Jager \& L. de W. Fourie \\ Departments of Marketing and Public Management, \\ Tshwane University of Technology, Pretoria, South Africa
}

\begin{abstract}
This paper investigates the level of importance of pre selected service quality variables of local passengers with regard to the services rendered to them when making use of domestic airlines in South Africa and Italy. This information is relevant for management decision making with regard to maintaining a competitive position in a highly competitive air transport industry. The need for the study resulted from a worldwide tendency of economic downturn and the public caution on air travel, which is caused by the capacity of the airline industry to exceed demand substantially. The aim of this paper is therefore to identify the most important variables that travellers in South Africa and Italy value and expect from a domestic airline service provider. The outcome of the research may offer better understanding with regard to service quality management in the airline industry in developing countries and developed countries and could result in developing competitive strategies based upon quality concepts.
\end{abstract}

Keywords: service quality, airlines, marketing, Italy, South Africa.

\section{Introduction}

The continuing support of transport business is dependent on imitative behaviour of travellers. According to Miller et al. [11] the most effective way to ensure imitative behaviour or repeat travellers are to provide a product or service that continuously meets the traveller's expectations. In reality, when endeavouring to deliver a service of continued quality, this task becomes formidable and, at times, impossible. 
The study attempts to investigate service quality elements that are associated with using a domestic airline in South Africa and to compare it with a similar study in Italy. This study attempts to act well in advance by identifying variables where special attention should be given to satisfy or even delight customers in order to maintain a competitive advantage over competitors (Lamb et al. [10]; Armstrong and Kotler, [2]).

\section{Literature review}

Over the past few years, the air transportation industry has become an increasingly important part of the economy and the tourism industry. It is an intercity mode of transportation for those passengers that must be transported quickly and efficiently (Wells and Wensveen [19]). One of aviation's final "products" is passenger's, safely and efficiently delivered to their destination (Shaw [16]). The airline product is not a physical item, but services that consumers can use. Safety, on-time reliability, convenience in terms of airport proximity or seat availability, frequency of departures, in-flight cabin services, ground services including ticketing and baggage handling, aircraft type and even the carrier's image are part of the airline product that can lead to service satisfaction. Airline companies started to realize the importance of understanding the needs of travellers (Wells and Wensveen [19]).

If the needs of the traveller is understood and adhered to, satisfaction is created. Satisfied travellers are repeat travellers. According to the purpose of travel, travellers have different needs. Safety and punctuality are needs of the business air traveller, and price and in-flight entertainment are more the needs of the leisure traveller (Shaw [16]). All markets (consumers) include groups of people with different product needs and preferences (Buhalis [4]). Airline companies need to design responsive products to meet the needs of the market (Semenik [15]) to ensure satisfaction. Market research is needed to determine the needs of different consumers. The aim of this paper is therefore to identify the most important variables that travellers value and expect from an airline service provider; and to determine service quality with regard to general flight service variables.

\subsection{Conceptualizing service quality}

Parasuraman et al. [14] conceptualized perceived service quality as a long-run overall evaluation about a service, whereas satisfaction is a transaction-specific evaluation. Based on these conceptualisations, Parasuraman et al. [14] posited that incidents of satisfaction over time result in perceptions of service quality. Johnston [9] came to the conclusion that there appears to be a consensus emerging that satisfaction refers to the outcome of individual service transactions and the overall service encounter, whereas service quality is the customer's overall impression of the relative inferiority/superiority of the organization and its services. Service quality therefore refers to a broader spectrum compared to satisfaction. Service quality is an important ingredient in the success of all 
service organisations. According to Devlin and Dong [5] research has shown that the provision of high quality service is directly and positively related to increased profits, market share and cost savings.

Perceived quality is a prerequisite for traveller satisfaction (Parasuraman et al. [14]). Several studies suggested that airline service quality is one of the most influential factors that are likely to influence traveller's airline selection decision and significant relationships exist among reputation, service, and retained preference (Truitt and Haynes [17]; Ostrowski et al. [12]). Service quality attributes that are perceived as important by airline travellers are price, safety, timelines, luggage transportation, quality of food and beverage, comfort of the seat, check-in process, and inboard services (Elliott and Roach [6]). In a comparison study of Swedish vs. US airline services, Swedish business passengers selected delays and cancelled flights as major reasons for the negative critical incidents whereas US businessmen had most of complaints about luggage handling followed by delays, pre flight or in-flight services, overbooking, cancelled flights, and others (Bejou et al. [3]). Tsaur et al. [18] found that comfort of the seat (tangibility), safety (reliability), and responsiveness and courtesy of attendants (responsiveness) are essential service attributes. Although service quality is one of the key factors in attracting and retaining loyal travellers, airlines are falling far short of the standard (Ostrowski et al. [12]). Airlines should recognize what their target travellers want in order to maximize traveller satisfaction. Air travellers are an integral part of the service process, which is one of the characteristics that distinguish services from products. Their involvement may be active or passive, but their presence influences what is perceived.

Based on the above it has become relevant for airlines to determine amongst others the purpose of travel of their travellers. In determination of the purpose of travel one can determine the needs and provide more specialized services. This will lead to higher levels of satisfaction and in the long-term loyalty. This will enable the airlines gain and/or hold the competitive

\section{Problem statement}

It is assumed that tour operators and airline management are planning their business with sufficient knowledge about the perception of tourists or passengers with regard to the services rendered to them. The problem under investigation in this paper is to investigate to what extent the services offered on domestic airlines are important to travellers and to compare it with the domestic airline industry in Italy. This should provide some extent of direction in order to satisfy client's need and consequently be profitable and to increase their market share. Gilbert and Wong [7, p. 520] state that in the airline industry context, the problem is whether management can perceive correctly what passengers want and expect. This becomes increasingly important resulting from the financial difficulties airlines are experiencing since the terrorist attacks of 11 September 2001 in the United States of America. The need for the study results from a worldwide tendency of economic downturn and the public caution on air travel, 
which is caused by the capacity of the airline industry to exceed demand substantially (Gursoy et al. [8, p.1]). The essence of the problem to be investigated is to determine whether South African airline travellers value service quality in the same way — using the same evaluation criteria - than their Italian counterparts. .

\section{Purpose of the study}

The purpose of this study is to investigate selective service quality elements that contribute to the satisfaction of tourists when making use of domestic airlines in South Africa. This will offer future research directions. The paper consists of an empirical study measuring selective service quality issues on board domestic airlines in South Africa and domestic airlines in Italy. The outcomes of the research will result in the sustainable management of service quality associated with the airline industry with specific reference to tourists. This is preceded by a literature study addressing service quality and the application of some strategies to ensure satisfied tourists on board domestic airlines.

\section{Objectives of the study}

The objective of the study is to determine the perceived importance of specified criteria in selecting an airline.

\subsection{Research hypotheses}

With regards to the objectives, the researchers formulated the following hypotheses:

- Ho: There exists no significant differences with regard to the importance of the service variables between the South African and the Italian samples

- Ha: There exist significant differences with regard to the importance of the service variables between the South African and the Italian samples.

\section{Research design and methodology}

A two-pronged approach was followed, namely a literature study and a survey. The qualitative (literature) study was done based on specific keywords. This included journal articles, conference papers, theses and dissertations, other tourism-related literature as well as sources on service satisfaction and service quality. Information searches were conducted mainly on library catalogues and indexes, as well as the Internet. This was done in order to identify the current relationship (if any) between service quality and decision-making.

The primary objective of the study is to identify the perceptions and resultant issues of importance with regard to pre selected service quality variables to tourists when making use of domestic airlines in South Africa. These results are then compared to the findings of a similar study in Italy. 


\subsection{Sample description}

Persons who have travelled by means of domestic airlines during the 12 months preceded the interview were screened and approached for their willingness to participate in the survey. Three hundred and forty one South African respondents agreed to be interviewed in the Tshwane region of South Africa and two hundred and fifty Italian respondents in the Verona district of Italy. The study was a follow up of a previous study in the same two regions.

With regard to the respondents occupations the majority of both sample groups were privately employed. The predominant age category of both groups was the category between 20 and 30 years of age. The largest proportion of both sample groups indicated they have flown within the last three months and that they have flown between 2 and 5 times during the last twelve months. The largest proportion of both samples has indicated that the main purpose of the travel was for business purposes. This also included at least one night of accommodation in a city or town away from home for especially the SouthAfrican sample.

While $81 \%$ of the Italian respondents travelled by economy class, $67 \%$ of South African respondents travelled by economy class.

\subsection{The measuring instrument}

The questionnaire was originally constructed by various inputs from both primary and secondary sources. Primary inputs were generated by focus groups that had prior experience of domestic airlines. Secondary inputs were collected from brochures and publications (Johnston [9]; Otto and Ritchie [13]). Eventually a questionnaire with similar inputs was used after permission was granted by the developer of the questionnaire (Aksoy et al. [1]). This was done for future comparative purposes. The questionnaire measured aspects like demographic information and the extent of important of service attributes when considering an airline. It included 38 pre identified service quality variables and was measured on a seven-point scale ranging from very important (1), important (2), somewhat important (3) not important nor unimportant (4), somewhat unimportant (5) unimportant (6) and not important at all (7). After the questionnaire was pilot tested, it was tested on 341 travellers on domestic airlines living in the Tshwane region of South Africa and 201 travellers in the Verona district of Italy. For the purpose of this study only three of the six identified categories (personnel issues; punctuality and speed; and cabin features are discussed as it has the biggest impact on the perceptions of the travellers.

To determine the reliability of the results a Cronbach Alpha test was performed which yielded reliability results of 0.88 and 0.91 for the Italian and South African samples respectively with regard to the different seven point scaled questions that were included in the questionnaire. A non-parametric test, the Kruskal-Wallis test was done to test the null hypothesis and the alternative hypothesis that there exists no significant difference between the levels of importance between the two groups and there exists significant differences between the groups (South-African sample and the Italian sample). 


\subsection{Administration of the measuring instrument}

Personal interviews were conducted with the respondents by means of a selfcompletion questionnaire that was drawn up in English and Italian. The South African fieldworkers were capable to assist in translating some of the issues to especially African languages. All the respondents in Italy were Italian citizens and could speak the Italian language or had knowledge of that language. Interviews were conducted at two different airports in the respective regions.

\subsection{Data analysis and capturing}

Data was analysed after grouping the list of 38 pre identified variables into seven logical groupings as to many factors arose after performing a factor analysis. The manual grouping resulted in a clear resemblance with one of the factor structures identified for the study mentioned previously. Most important variables for each grouping were highlighted and compared between the two countries.

Data was captured by a trained assistant and analysed using the SPSS version 12 statistical package.

\section{Findings of the research}

Table 1 indicates that significant differences exist between both samples with regard to all cabin feature related issues except the cabin cleanliness where no significant difference between the two samples exist. The latter is overall regarded as most important variable in this category while both samples responded accordingly. However the Italian sample regards this issue significantly more important compared to the South African sample. This is followed by the comfort ness of the seats where Italians again measured a higher degree of importance to this variable. Overall the carry on storage space is rated least important in this category while the distinctive samples showed similar results. However significant differences between the two samples exist with South Africans valued this variable less important compared to the Italians.

According to table 2 significant differences between the two samples were measured between all variable in this category except for the ability of the cabin crew to speak foreign languages and close attention by the cabin crew. Overall the convenience in making bookings (other than through the internet) measured most important while the South African sample held a stronger opinion in favour of the particular variable. The Italian sample rated this variable in third position while they rated close attention by the cabin crew most important Overall, the second most important issue measured was close attention by the cabin crew. No significant differences were measured. Overall the variable that was rated least important in this category was the cabin crew's ability to speak a foreign language. While no significant difference is measured, the Italian sample regarded this variable less important.

Table 3 indicates that on time arrivals is overall and distinctively the most important variable amongst all 28 pre identified variables. In addition no 
significant difference in this regard is measured between the two samples. The second overall most important variable is on time luggage delivery on arrival. While South Africans rated the variable in second place it was rated fourth by the Italians with significant less importance to the latter country. The least overall important variable in this category is frequent flights to destinations with South Africans expressing stronger views in this regard.

Table 1: $\quad$ Cabin features.

\begin{tabular}{|c|c|c|c|c|c|c|c|}
\hline $\begin{array}{l}\text { Cabin } \\
\text { features }\end{array}$ & \multicolumn{2}{|c|}{$\begin{array}{l}\text { South } \\
\text { Africa }\end{array}$} & \multicolumn{2}{|c|}{ Italy } & \multicolumn{2}{|c|}{ Total } & \\
\hline $\begin{array}{l}\text { Item wording } \\
\text { and item }\end{array}$ & $\mathrm{Mn}$ & SD & $\mathrm{Mn}$ & SD & $\mathrm{Mn}$ & SD & $\begin{array}{l}\text { Result of } \\
\text { hypotheses test }\end{array}$ \\
\hline $\begin{array}{l}\text { Cabin } \\
\text { temperature } \\
\text { V102 }\end{array}$ & $\begin{array}{c}2.16 \\
3\end{array}$ & 1.37 & $\begin{array}{c}2.85 \\
4\end{array}$ & 1.42 & $\begin{array}{c}2.32 \\
3\end{array}$ & 1.41 & $\begin{array}{l}\text { sig. }=0.05 \\
\text { df }=1 \\
\text { p-value }=0.0001 \\
\text { Conclusions: Ho reject }\end{array}$ \\
\hline $\begin{array}{l}\text { Comfort of } \\
\text { seats } \\
\text { V104 }\end{array}$ & $\begin{array}{c}2.11 \\
2\end{array}$ & 1.85 & $\begin{array}{c}1.86 \\
2\end{array}$ & 0.83 & $\begin{array}{c}2.05 \\
2\end{array}$ & 1.67 & $\begin{array}{l}\text { sig. }=0.05 \\
\text { df }=1 \\
\text { p-value }=0.0444 \\
\text { Conclusions: Ho reject }\end{array}$ \\
\hline $\begin{array}{l}\text { Cabin } \\
\text { ventilation } \\
\text { V107 }\end{array}$ & $\begin{array}{c}2.34 \\
4\end{array}$ & 1.7 & $\begin{array}{c}2.54 \\
3\end{array}$ & 1.26 & $\begin{array}{c}2.39 \\
4\end{array}$ & 1.61 & $\begin{array}{l}\text { sig. }=0.05 \\
\text { df }=1 \\
\text { p-value }=0.0012 \\
\text { Conclusions: Ho reject }\end{array}$ \\
\hline $\begin{array}{l}\text { Carry on } \\
\text { storage space } \\
\text { V110 }\end{array}$ & $\begin{array}{c}2.58 \\
5\end{array}$ & 1.58 & $\begin{array}{c}3.03 \\
5\end{array}$ & 1.41 & $\begin{array}{c}2.68 \\
5\end{array}$ & 1.55 & $\begin{array}{l}\text { sig. }=0.05 \\
\text { df }=1 \\
\text { p-value }=0.0001 \\
\text { Conclusions: Ho reject }\end{array}$ \\
\hline $\begin{array}{l}\text { Cabin } \\
\text { cleanliness } \\
\text { V112 }\end{array}$ & $\begin{array}{c}2.06 \\
1\end{array}$ & 1.63 & $\begin{array}{c}1.85 \\
1\end{array}$ & 0.77 & $\begin{array}{c}2.01 \\
1\end{array}$ & 1.48 & $\begin{array}{l}\text { sig. }=0.05 \\
\text { df }=1 \\
\text { p-value }=0.1457 \\
\text { Conclusions: Ho accept }\end{array}$ \\
\hline
\end{tabular}

\section{Conclusion and management implications}

The study attempts to reveal the most important service quality variables associated with an airline when choosing a specific airline. It is useful to identify specific drivers of airline service quality that most relate to the passengers as appropriate intervention strategies can then be formulated. Simply meeting passengers' adequate service expectations may not be good enough for airlines to survive the rivalry (Gilbert and Wong [7]). Knowledge about this is particularly important for decision makers who should be aware of what travellers regard as the most important issues in order to cater for their needs. The overall most important variable as indicated by both samples is, on time departures and arrivals followed by on time luggage delivery on arrival and speed check in services. Consequently prompt departures and arrival services should be regarded priority as most of the respondents are business people who operate on 
a tight time schedule and consequently will not tolerate continues late departures from airlines who is well known for causing delays. These three variables were categorised under punctuality and speed. Under the personnel category, the

Table 2: $\quad$ Personnel issues.

\begin{tabular}{|c|c|c|c|c|c|c|c|}
\hline $\begin{array}{l}\text { Personnel } \\
\text { issues }\end{array}$ & \multicolumn{2}{|c|}{$\begin{array}{l}\text { South } \\
\text { Africa }\end{array}$} & \multicolumn{2}{|c|}{ Italy } & \multicolumn{2}{|c|}{ Total } & \\
\hline $\begin{array}{l}\text { Item wording } \\
\text { and item }\end{array}$ & $\mathrm{Mn}$ & SD & $\mathrm{Mn}$ & SD & $\mathrm{Mn}$ & SD & $\begin{array}{l}\text { Result of } \\
\text { hypotheses test }\end{array}$ \\
\hline $\begin{array}{l}\text { Convenience } \\
\text { in making } \\
\text { reservations/ } \\
\text { bookings } \\
\text { V103 }\end{array}$ & $\begin{array}{c}1.97 \\
1\end{array}$ & 1.38 & $\begin{array}{c}2.33 \\
3\end{array}$ & 1.2 & $\begin{array}{c}2.06 \\
1\end{array}$ & 1.34 & $\begin{array}{l}\text { sig. }=0.05 \\
\text { df }=1 \\
\text { p-value }=0.0001 \\
\text { Conclusions: Ho reject }\end{array}$ \\
\hline $\begin{array}{l}\text { Personnel's } \\
\text { ability to keep } \\
\text { clients } \\
\text { informed } \\
\text { about all types } \\
\text { of flight info } \\
\text { V106 }\end{array}$ & $\begin{array}{c}2.31 \\
5\end{array}$ & 1.51 & $\begin{array}{c}2.86 \\
8\end{array}$ & 1.45 & $\begin{array}{c}2.45 \\
6\end{array}$ & 1.51 & $\begin{array}{l}\text { sig. }=0.05 \\
\mathrm{df}=1 \\
\text { p-value }=0.0001 \\
\text { Conclusions: Ho reject }\end{array}$ \\
\hline $\begin{array}{l}\text { Personnel's } \\
\text { ability to } \\
\text { innovation and } \\
\text { improvement } \\
\text { in services } \\
\text { V108 }\end{array}$ & $\begin{array}{c}2.3 \\
4\end{array}$ & 1.59 & $\begin{array}{c}2.54 \\
6\end{array}$ & 1.1 & $\begin{array}{c}2.36 \\
4\end{array}$ & 1.49 & $\begin{array}{l}\text { sig. }=0.05 \\
\mathrm{df}=1 \\
\text { p-value }=0.0002 \\
\text { Conclusions: Ho reject }\end{array}$ \\
\hline $\begin{array}{l}\text { Physical } \\
\text { appearance of } \\
\text { cabin crew } \\
\text { V114 }\end{array}$ & $\begin{array}{c}2.27 \\
3\end{array}$ & 1.59 & $\begin{array}{c}2.41 \\
4\end{array}$ & 1.06 & $\begin{array}{c}2.3 \\
3\end{array}$ & 1.49 & $\begin{array}{l}\text { sig. }=0.05 \\
\mathrm{df}=1 \\
\text { p-value }=0.003 \\
\text { Conclusions: Ho reject }\end{array}$ \\
\hline $\begin{array}{l}\text { Cabin crew's } \\
\text { credibility } \\
\text { V116 }\end{array}$ & $\begin{array}{c}2.54 \\
8\end{array}$ & 1.71 & $\begin{array}{c}2.01 \\
2\end{array}$ & 0.96 & $\begin{array}{c}2.41 \\
5\end{array}$ & 1.58 & $\begin{array}{l}\text { sig. }=0.05 \\
\mathrm{df}=1 \\
\text { p-value }=0.041 \\
\text { Conclusions: Ho reject }\end{array}$ \\
\hline $\begin{array}{l}\text { Cabin crew's } \\
\text { ability to } \\
\text { answer } \\
\text { questions } \\
\text { V118 }\end{array}$ & $\begin{array}{c}2.47 \\
7\end{array}$ & 1.78 & $\begin{array}{c}2.52 \\
5\end{array}$ & 1.25 & $\begin{array}{c}2.48 \\
7\end{array}$ & 1.67 & $\begin{array}{l}\text { sig. }=0.05 \\
\mathrm{df}=1 \\
\text { p-value }=0.018 \\
\text { Conclusions: Ho reject }\end{array}$ \\
\hline $\begin{array}{l}\text { Cabin crew's } \\
\text { ability to } \\
\text { speak foreign } \\
\text { languages } \\
\text { V123 }\end{array}$ & $\begin{array}{c}2.19 \\
2\end{array}$ & 1.81 & $\begin{array}{c}2.73 \\
7\end{array}$ & 1.4 & $\begin{array}{c}2.87 \\
8\end{array}$ & 1.72 & $\begin{array}{l}\text { sig. }=0.05 \\
\mathrm{df}=1 \\
\text { p-value }=0.903 \\
\text { Conclusions: Ho accept }\end{array}$ \\
\hline $\begin{array}{l}\text { Close attention } \\
\text { by cabin crew } \\
\text { V128 }\end{array}$ & $\begin{array}{c}2.33 \\
6\end{array}$ & 1.67 & $\begin{array}{c}1.87 \\
1\end{array}$ & 0.72 & $\begin{array}{c}2.21 \\
2\end{array}$ & 1.5 & $\begin{array}{l}\text { sig. }=0.05 \\
\mathrm{df}=1 \\
\text { p-value }=0.381 \\
\text { Conclusions: Ho accept }\end{array}$ \\
\hline
\end{tabular}


convenience in making reservations/ bookings at a travel agency is regarded as most important service quality variable. Although the internet is supplementing this service, travell agents accociated with the respective airlines should be informed about the important role they are playing in the service providing process. Close attention by the cabin crew has been regarded second most important in this category. Close related to this issue and third most important variable is the physical appearance of the crew members. In this regard management should pay special attention to this issues when crew members undergo their training. With regard to cabin features, the cleanliness and comfortness of seats should get special attention. All mentioned variable should be closely monitored in order to maintain a competative advantage in an environment were supply often exceeds demand. In conclusion the survey has attempted to provide usefull information with regard to differences in importance between Italian and South African passangers when aking use of their respective domestic airlines. Only three of the seven identified categories were included for the purpose of this paper, being rated the most important three categories.

Table 3: $\quad$ Punctuality and speed.

\begin{tabular}{|c|c|c|c|c|c|c|c|}
\hline $\begin{array}{l}\text { Punctuality and } \\
\text { speeds }\end{array}$ & \multicolumn{2}{|c|}{$\begin{array}{l}\text { South } \\
\text { Africa }\end{array}$} & \multicolumn{2}{|c|}{ Italy } & \multicolumn{2}{|c|}{ Total } & \\
\hline $\begin{array}{l}\text { Item wording } \\
\text { and item }\end{array}$ & $\mathrm{Mn}$ & $\mathrm{SD}$ & $\mathrm{Mn}$ & SD & $\mathrm{Mn}$ & SD & $\begin{array}{l}\text { Result of } \\
\text { hypotheses test }\end{array}$ \\
\hline $\begin{array}{l}\text { On time departures } \\
\text { and arrivals V91 }\end{array}$ & $\begin{array}{c}1.63 \\
1\end{array}$ & 1.16 & $\begin{array}{c}1.46 \\
1\end{array}$ & 0.76 & $\begin{array}{c}1.59 \\
1\end{array}$ & 1.08 & $\begin{array}{l}\text { sig. }=0.05 \\
\mathrm{df}=1 \\
\text { p-value }=0.381 \\
\text { Conclusions: } \\
\text { Ho accept }\end{array}$ \\
\hline $\begin{array}{l}\text { On time luggage } \\
\text { delivery on arrival } \\
\text { V92 }\end{array}$ & $\begin{array}{c}1.70 \\
2\end{array}$ & 1.09 & $\begin{array}{c}2.07 \\
4\end{array}$ & 1.44 & $\begin{array}{c}1.78 \\
2\end{array}$ & 1.19 & $\begin{array}{l}\text { sig. }=0.05 \\
\mathrm{df}=1 \\
\text { p-value }=0.004 \\
\text { Conclusions: } \\
\text { Ho reject }\end{array}$ \\
\hline $\begin{array}{l}\text { Speed check in } \\
\text { services V90 }\end{array}$ & $\begin{array}{c}1.78 \\
3\end{array}$ & 1.25 & $\begin{array}{c}2.18 \\
5\end{array}$ & 0.92 & $\begin{array}{c}1.87 \\
3\end{array}$ & 1.19 & $\begin{array}{l}\text { sig. }=0.05 \\
\mathrm{df}=1 \\
\text { p-value }=0.001 \\
\text { Conclusions: } \\
\text { Ho reject }\end{array}$ \\
\hline $\begin{array}{l}\text { Direct service to } \\
\text { destination V95 }\end{array}$ & $\begin{array}{c}2.1 \\
4\end{array}$ & 1.45 & $\begin{array}{c}1.74 \\
2\end{array}$ & 0.78 & $\begin{array}{c}2.02 \\
4\end{array}$ & 1.34 & $\begin{array}{l}\text { sig. }=0.05 \\
\mathrm{df}=1 \\
\text { p-value }=0.198 \\
\text { Conclusions: } \\
\text { Ho accept }\end{array}$ \\
\hline $\begin{array}{l}\text { Frequent flights to } \\
\text { destination V } 96\end{array}$ & $\begin{array}{c}2.3 \\
5\end{array}$ & 1.45 & $\begin{array}{c}1.75 \\
3\end{array}$ & 0.78 & $\begin{array}{c}2.38 \\
5\end{array}$ & 1.55 & $\begin{array}{l}\text { sig. }=0.05 \\
\mathrm{df}=1 \\
\text { p-value }=0.743 \\
\text { Conclusions: } \\
\text { Ho accept }\end{array}$ \\
\hline
\end{tabular}




\section{References}

[1] Aksoy, S., Atilgan, E. \& Akinci, S. Airline service marketing by domestic and foreign firms: differences from the customers' viewpoint. Journal of Air Transport Management, 9(6), pp 343-351. November 2003.

[2] Armstrong, G. \& Kotler, P. 2003. Marketing. An introduction. New Jersey: Prentice Hall.

[3] Bejou, D., Edvardsson, B. \& Rakowski, J.P., A critical incident approach to examining the effects of service failures on traveller relationships: The case of Swedish and U.S. Airlines. Journal of Travel research, 35(1), pp 35-40, 1996.

[4] Buhalis, D., Marketing the competitive destination of the future. Tourism management, 21(1), pp 97-116, Feb 2000.

[5] Devlin, S. \& Dong, U.K., Service quality from the customers' perspective," in Service Marketing, Lovelock, Christian H, ed. Upper Sadie River: Prentice Hail, 1994.

[6] Elliott, K. \& Roach, D.W., Service quality in the airline industry: Are carriers getting an unbiased evaluation from consumers? Journal of Professional Service Marketing, 9(2), pp 71-82, 1993.

[7] Gilbert, D. \& Wong, R.K.C., Passenger expectations and airline services: a Hong Kong based study. Tourism Management, 24(5), pp. 519 - 532, 2003.

[8] Gursoy, D., Chen, M. \& Kim, H.J. The US airlines relative positioning based on attributes of service quality. Tourism Management, Article in press, 2003.

[9] Johnston, R., The determinants of service quality: satisfiers and dissatisfiers. International Journal of Service Industry Management, 6(5): 53-71, 1995.

[10] Lamb, W., Hair, J.F., McDaniel, C., Boshoff, C. \& Terblanche, N. Marketing. Cape Town: Oxford University Press, 2004.

[11] Miller, J.L., Craighead, C. \& Karwan, K.R., Service recovery: a framework and empirical investigation. Journal of operations management, (18), pp 387- 400, January 2000.

[12] Ostrowski, P L., O’Brien, T.V. \& Gordon, G.L., Service quality and traveller loyalty in the commercial airline industry. Journal of Travel Research, 32(2), pp 16- 24, 1993.

[13] Otto, E. \& Brent Ritchie, J.R., The service experience in tourism, Tourism Management, 17(3), pp 165-174, 1996.

[14] Parasuraman, A., Zeithaml, V.A. \& Berry, L.L., SERVQUAL: A multiple item scale for measuring consumer's perceptions of service quality. Journal of retailing, 64(1), pp 12 -40, 1988.

[15] Semenik, R.J., Promotion and integrated marketing communications. Canada: Thomson Learning. 2003.

[16] Shaw, S., Airline marketing and management. 3 ed. London: Pitman.

[17] Truitt, L. \& Haynes, R., Evaluating service quality and productivity in the regional airline industry, Transport Journal, 33(4) pp 21-32, 1994. 
[18] Tsaur, S.H., Chang, T.Y. \& Yen, C.H., The evaluation of airline service quality by fuzzy MCDM, Tourism Management, 23(2), pp 107-115, 2002.

[19] Wells, A.T. \& Wensveen, J.G., Air transportation: a management perspective, $5^{\text {th }}$ ed. Belmont: Thomson learning, 2004. 